\title{
Greenhouse Gas Emission Estimation for Selected Crops and Rice Cultivation in Urban and Non-Urban Areas of Sarawak
}

\author{
N.Azimah. Bahrum ${ }^{1, *}, M$. A. Malek ${ }^{1,2}$, and C.S. $\operatorname{Tan}^{3}$ \\ ${ }^{1}$ Department of Civil Engineering, Universiti Tenaga Nasional, Jalan IKRAM-UNITEN, 43000 \\ Kajang, Selangor, Malaysia \\ ${ }^{2}$ Centre for Renewable Energy (CRE), Universiti Tenaga Nasional, Jalan IKRAM-UNITEN, 43000 \\ Kajang, Selangor, Malaysia \\ ${ }^{3}$ Institute of Energy Policy and Research (IEPRe), Universiti Tenaga Nasional, Jalan IKRAM \\ UNITEN, 43000 Kajang, Selangor, Malaysia
}

\begin{abstract}
This study presents an updated estimation of annual Greenhouse Gas (GHG) emission from crop and rice cultivations from year 2008 to 2012 in Sarawak. This includes GHG estimation from rice cultivations, biomass and soils organic. The estimation of GHG emission in this study is conducted in accordance to 2006 IPCC guidelines for Agriculture, Forestry and Other Land Use (AFOLU) sector, where uncertainty analyses are incorporated. This study also presents findings at urban and non-urban areas of Sarawak and its comparisons. It is found that, the change in biomass for both urban and non-urban areas in Sarawak increases yearly with significant changes in biomass at urban areas at

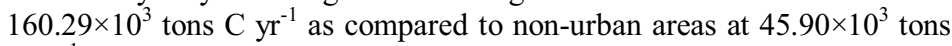
$\mathrm{C} \mathrm{yr}^{-1}$. It is also found that, the annual carbon loss from cultivated organic soil at urban areas is higher at $6.17 \times 10^{6}$ tons $\mathrm{C}^{-1}{ }^{-1}$ in Miri. Total $\mathrm{CH}_{4}$ emission from wet paddy in non-urban areas is found to be higher than urban areas at $19.01 \mathrm{Gg} \mathrm{CH}_{4} \mathrm{yr}^{-1}$. This study would unable relevant authorities to use the values of GHG emission estimated in this study for the purpose of analysis on vulnerability, adaption and mitigation.
\end{abstract}

\section{Introduction}

Malaysia has signed the United Nations Framework Convention on Climate Change (UNFCCC) on 9 June 1993 and ratified it on 13 July 1994. Even though, Malaysia has no official obligations toward reducing emission of greenhouse gases (GHG) under the Kyoto Protocol as a signatory to the UNFCCC, Malaysia has an obligation to report its GHG inventory to UNFCCC [1]. Gases such as methane $\left(\mathrm{CH}_{4}\right)$ and nitrous oxide $\left(\mathrm{N}_{2} \mathrm{O}\right)$ are the main two gases in agriculture sector besides carbon dioxide $\left(\mathrm{CO}_{2}\right)$. GHG is being estimated as part of the GHG inventory preparation and 2006 IPCC guidelines are used.

\footnotetext{
*Corresponding author: azimah.bahrum@gmail.com
} 
It covers four (5) main sectors; energy, waste, industrial processes, land use, land use change and forestry (LULUCF) and Agriculture, Forestry and Other Land Use (AFOLU) sector [8]. The GHGs productions and global warming phenomena do not only impact the environment and economy, it also leaves conspicuous effects on human health. This study focuses on GHG emission emitted from cropland sector at urban (Kuching, Miri and Sibu) and non-urban (Limbang, Sri Aman and Betong) areas in Sarawak, Malaysia.

\section{Backgrounds}

Sarawak is one of the major agriculture producers in Malaysia. The total area classification for agriculture sector is $1,779,190$ hectare. This study shows GHG emission from palm oil plantations at $68.2 \%$ and rice cultivations at $9.16 \%$ which are pertinent agricultural products in Sarawak. Based on review from Sarawak Gross Domestic Product (GDP) in 2012, agriculture sector is the second output of Sarawak by $15.1 \%$ [7]. Hence, it is a large potential source of GHG emission in Sarawak. GHG emissions may contribute to global warming phenomena due to its increment in atmospheric concentrations.

Greenhouse gas (GHG) is a gas in the atmosphere that absorbs and emits radiation within thermal infrared range. This process is fundamental because of the greenhouse effect. The greenhouse gases of concerned are carbon dioxide $\left(\mathrm{CO}_{2}\right)$, nitrous oxide $\left(\mathrm{N}_{2} \mathrm{O}\right)$, and methane $\left(\mathrm{CH}_{4}\right)$. Formation of greenhouse gases from precursor gases is considered as an indirect emission. Activities in AFOLU such as management of croplands, forests, grasslands and wetlands contributed to anthropogenic GHG emission. In Malaysia, statistics showed that 3\% of its GHG emission is from agriculture sector [2]. In order to observe this situation, monitoring efforts in this sector need to be established.

This study aims to estimate the amount and trending of GHG emissions from urban areas of Sarawak namely Kuching, Miri and Sibu as well as GHG emissions from nonurban areas namely Limbang, Sri Aman and Betong for cropland sector at the period of 2008 - 2012 years using 2006 IPCC guidelines. These areas are categorized based on several factors namely, gross domestic product, population size, infrastructural facilities, industrial and economy developments, standard of living and education level.

\section{Methodology}

Being a developing country, data collection for GHG emission on AFOLU is still at an infant stage in Malaysia. Through data exploration conducted, the state of Sarawak was found to have no regional specific data available, therefore Tier 1 methodology approach in 2006 IPCC guidelines was utilised.

This study uses the Tier 1 methodology of 2006 IPCC (Intergovernmental Panel on Climate Change) Guidelines in selected crops and rice cultivation has been applied to estimate $\left(\mathrm{CO}_{2}\right)$ and $\left(\mathrm{CH}_{4}\right)$ emissions in Sarawak, within the years from 2008 to 2012 and that gas emission inventory has been developed in this study, based on volume 4, 2006 IPCC Guidelines. The selected crops grown in Sarawak are paddy (wet cultivation), oil palm, rubber, coconut and pepper. Data collection is an important stage in any area of study. In this study emission of $\mathrm{CO}_{2}$ are estimated from biomass cropland and $\mathrm{CH}_{4}$ from rice cultivation. 


\section{Estimation of GHG Emission}

Estimation of annual greenhouse gas emission from Cropland remaining Cropland includes biomass, soils organic matter and methane emissions from rice cultivation. In this study, the values GHG emissions are calculated using formula's provided in 2006 IPCC.

\subsection{Annual Change in Carbon Stocks in Biomass, $\Delta C_{B}$ (tons $C \mathrm{yr}^{-1}$ )}

Changes in carbon for cropland biomass are estimated from annual rates of biomass gain and loss. The annual change of carbon stocks in biomass calculation for each sub-category cropland is shown in Equation 1, 2006 IPCC guidelines;

$$
\Delta C_{B}=\Delta C_{G}-\Delta C_{L}
$$

where;

$\Delta \mathrm{C}_{\mathrm{G}}=$ Annual increase in carbon stocks, tons $\mathrm{C} \mathrm{yr}^{-1}$ which annual area [3] of cropland multiply biomass accumulation rates, $\mathrm{G}$ [4].

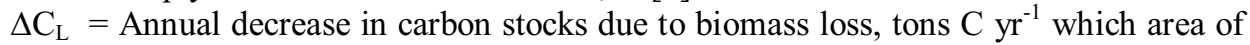
harvest is assumed to consist of $10 \%$ of total annual area [3] of cropland multiply biomass carbon loss, L under climate region category of tropical, moist [4].

\subsection{Annual Change in Carbon Stocks in Mineral Soils, $\Delta C_{\text {Mineral }}$ (tons $C \mathrm{yr}^{-1}$ )}

Soils with high carbon content are called organic soils. Other soils with less carbon content are generally referred to as mineral soils [5]. Calculations on annual change in carbon stocks at each sub-category of cropland are conducted based on Equation 2, 2006 IPCC;

$$
\Delta C_{\text {mineral }}=\frac{\left(S O C_{o}-S O C_{(0-T)}\right.}{D}
$$

where;

$\mathrm{SOC}_{0}=$ Soil organic carbon stock in the last year of an inventory time period, tonnes $\mathrm{C}$.

$\mathrm{SOC}_{(0-\mathrm{T})}=$ Soil organic carbon stock at the beginning of the inventory time period, tonnes $\mathrm{C}$.

$\mathrm{D}=$ Time dependence of stock change factors.

\subsection{Annual Carbon Loss from Cultivated Organic Soils, Lorganic (tons $C \mathrm{yr}^{-1}$ )}

Soils with high carbon content are called organic soils. Organic soils are common in wetland soils [5]. Calculations on annual carbon loss from cultivated organic soils at each sub-category of cropland are conducted based on Equation 3, 2006 IPCC;

$$
L_{\text {organic }}=\sum(A x E F)
$$

where;

$\mathrm{A}=$ Area of cropland, ha [1]. 


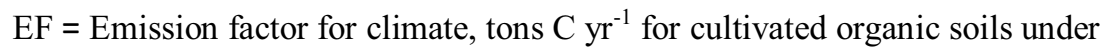
climatic temperature regime category of tropical/ sub-tropical used is 20.0 - Table $5.6[4]$.

\subsection{Methane emission from rice cultivation, $\mathrm{CH}_{4 \text { Rice }}\left(\mathrm{Gg} \mathrm{CH}_{4} \mathrm{yr}^{-1}\right)$}

The annual amount of $\mathrm{CH}_{4}$ emitted from a given area of rice and duration of crops grown, water regimes before and during cultivation period, soil type, temperature, and rice cultivar. Estimation on annual methane emissions from rice cultivation is based on Equation 4, 2006 IPCC guidelines;

$$
C H_{4 \text { Rice }}=\sum E F_{i} \times t \times A \times 10^{-6}
$$

where;

$\mathrm{EF}_{\mathrm{i}}=\mathrm{A}$ daily emission factor, $\mathrm{kg} \mathrm{CH}_{4} \mathrm{ha}^{-1}$ day $^{-1}$ [4].

$\mathrm{t}=$ Cultivation period of rice, day is assumed to eight (8) month or 240 days.

$\mathrm{A} \quad=$ Annual harvested area of rice, ha $\mathrm{yr}^{-1}[3]$.

\subsection{Uncertainty Analyses}

In this study, the uncertainty analyses calculation is assumed to use a normal distribution, with a $95 \%$ confidence interval (CI) of $30 \%$ from Mean of Tier 1 . The emission factors used in the uncertainty analyses were extracted from 2001 IPCC guidelines [6]. The uncertainty analyses conducted is based on Equation 5 and Equation 6.

$$
U_{\text {total }}=\sqrt{U_{1}^{2}+U_{2}^{2}+\ldots .+U_{n}^{2}}
$$

where;

$\mathrm{U}_{\text {total }}=$ The percentage uncertainty in the product of the quantities (half the 95 percent confidence interval divided by the total and expressed as a percentage).

$\mathrm{U}_{1} \quad=$ The percentage uncertainties associated with each of the quantities.

where;

$$
U_{\text {total }}=\sqrt{\frac{\left(U_{1} \cdot x_{1}\right)^{2}+\left(U_{2} \cdot x_{2}\right)^{2}+\ldots \ldots+\left(U_{n} \cdot x_{n}\right)^{2}}{\left|x_{1}+x_{2}+\ldots \ldots+x_{n}\right|}}
$$

$\mathrm{U}_{\text {total }} \quad=$ The percentage uncertainty in the sum of the quantities.

$x_{1}$ and $U_{1}=$ The uncertain quantities and the percentage uncertainties associated with them, respectively.

\section{Results}

\subsection{Carbon Dioxide $\left(\mathrm{CO}_{2}\right)$}

$\mathrm{CO}_{2}$ are determined from estimating changes in carbon stocks for biomass cropland from year 2008 till 2012 as shown in Fig. 1. In this study, the change in biomass is calculated for perennial crops in urban (Kuching, Miri and Sibu) and non-urban (Limbang, Sri Aman and 
Betong) areas of Sarawak. The selected crops in Sarawak are pepper, coconut, oil palm, paddy and rubber. It is found that, the change in biomass for both urban and non-urban areas increases yearly. The change in biomass at urban areas is more significant as compared to non-urban areas. Miri which is categorized as an urban area shows an amount

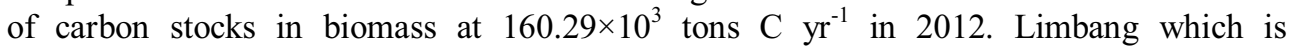
categorized as non-urban area exhibited small changes for carbon stocks in biomass at $13.03 \times 10^{3}$ tons $\mathrm{C} \mathrm{yr}^{-1}$ in year 2012 .

In this study, the total uncertainties trend on $\mathrm{CO}_{2}$ emission from biomass cropland is approximately 5.87\% for Kuching, 2.20\% for Miri, 16.73\% for Sibu, 9.48\% for Limbang, $21.13 \%$ for Sri Aman and $25.17 \%$ for Betong. The emission factors used in the uncertainty analyses were extracted from 2006 IPCC guidelines.

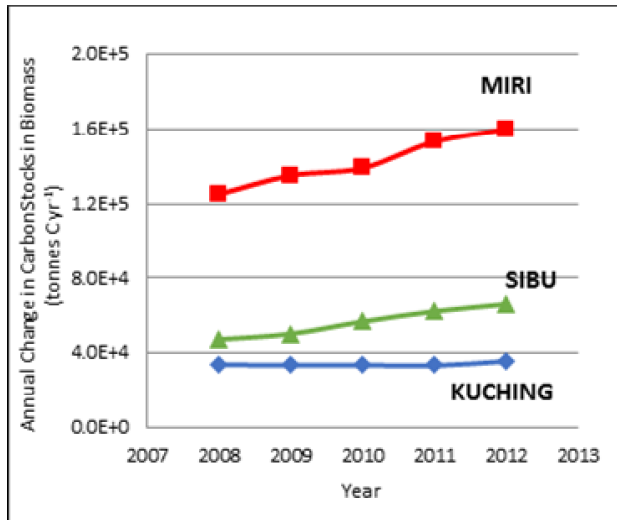

(a)

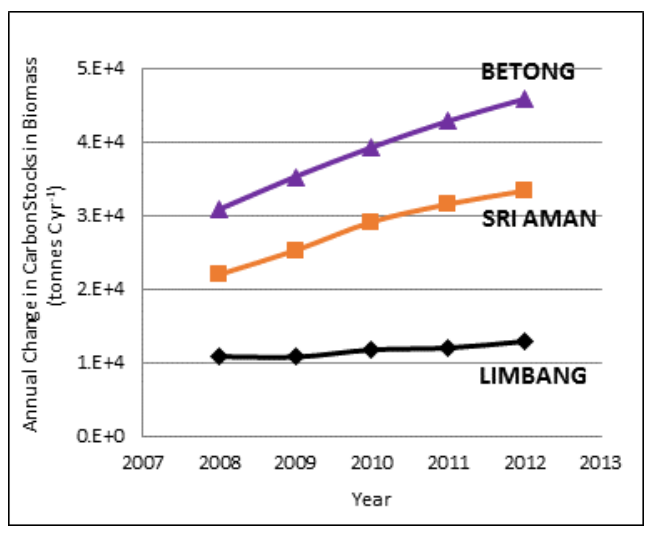

(b)

Fig. 1. Total annual change for carbon stocks in biomass (tons $\mathrm{C} \mathrm{yr}^{-1}$ ) from perennial crops at (a) urban and (b) non-urban areas of Sarawak for year 2008-2012.

There have two types of soils organic, which is mineral soils and organic soils. For this study, types of soil organic for oil palm in Sarawak are under organic soils. The Fig. 2 showed the result of annual carbon loss of cultivated organic soil from year 2008 till 2012. In order to assign an annual emission factor to estimate the losses of $\mathrm{C}$, in accordance to the area of drained and managed organic soils under each climate type, it is multiplied by the associated emission factor to derive an estimate of annual $\mathrm{CO}_{2}$ emissions. In this study, it is found that, the annual carbon loss from cultivated organic soil for palm oil at urban areas is higher where the annual carbon loss in Miri is at $6.17 \times 10^{6}$ tons $\mathrm{C} \mathrm{yr}^{-1}$ in year 2012. The annual carbon loss from cultivated organic soil at non-urban area is found to be lower,

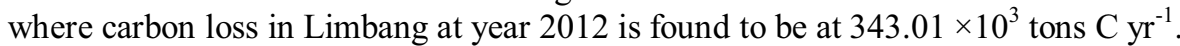

Other soils with less carbon content are generally referred to as mineral soils. The selected crops in Sarawak are pepper, coconut, rubber and paddy. Fig. 3 shows the total value annual changes in carbon stocks for mineral soils of perennial crops in Sarawak. It is found that from year 2008 to 2012 the net change in mineral soils for perennial crops at Kuching, Miri and Sibu respectively is 14692.74 tonnes $\mathrm{C} \mathrm{yr}^{-1}, 2770.39$ tonnes $\mathrm{C} \mathrm{yr}{ }^{-1}$ and 6497.46 tonnes $\mathrm{C} \mathrm{yr}^{-1}$. In this study, it is found that, the net change in mineral soils for perennial crops at Kuching is higher than Miri and Sibu. While, it is found at Limbang, Sri Aman and Betong respectively is 1250.72 tonnes $\mathrm{C} \mathrm{yr}{ }^{-1}, 2953.72$ tonnes $\mathrm{C} \mathrm{yr}^{-1}$ and 10991.82 tonnes $\mathrm{C} \mathrm{yr}^{-1}$ for non-urban areas. In this study, it is found that, the net change in mineral soils for perennial crops at Betong is higher than Limbang and Sri Aman. 


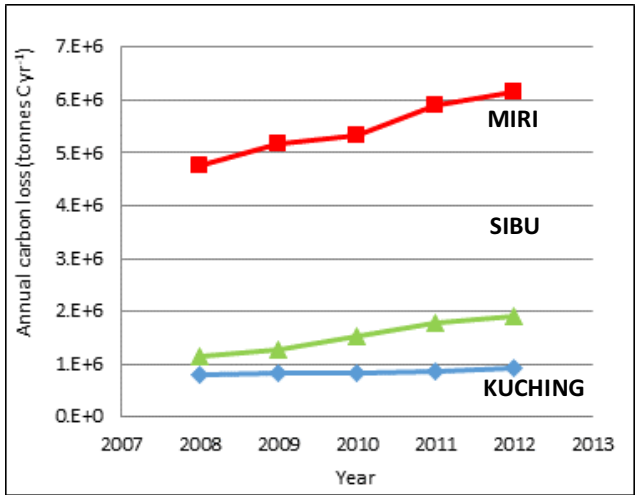

(a)

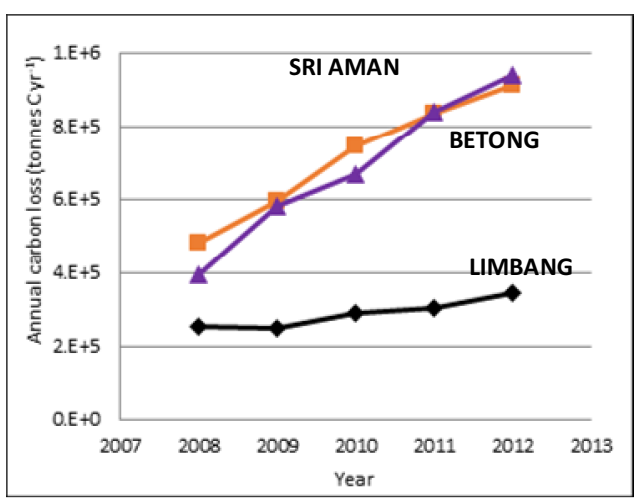

(b)

Fig. 2. Total annual carbon loss from cultivated organic soils, $\mathrm{L}_{\text {Organic }}\left(\right.$ tonnes $\mathrm{C} \mathrm{yr}^{-1}$ ) for palm oil in (a) urban and (b) non-urban areas of Sarawak for year 2008 - 2012.

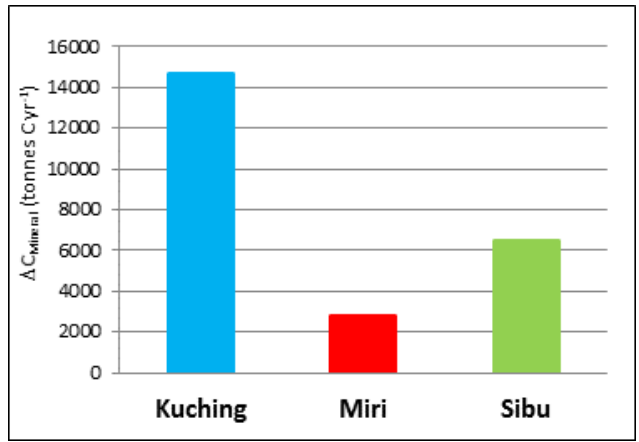

(a)

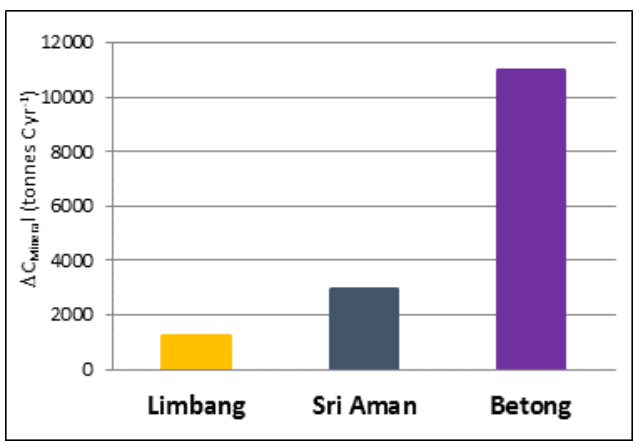

(b)

Fig. 3. Total annual change in carbon stocks for mineral soils, $\Delta \mathrm{C}_{\text {Mineral }}\left(\right.$ tonnes $\mathrm{C} \mathrm{yr}^{-1}$ ) of perennial crop in (a) urban and (b) non-urban areas of Sarawak for year 2008-2012.

In this study, the total uncertainties trend on $\mathrm{CO}_{2}$ emission from soils organic is approximately $1.70 \%$ for Kuching, $1.83 \%$ for Miri, $4.72 \%$ for Sibu, 3.88\% for Limbang, $2.70 \%$ for Sri Aman and $9.92 \%$ for Betong. 2006 IPCC guidelines showed a low uncertainty factor for estimation of area under different cropping systems at less than $10 \%$ $(<10 \%)[4]$.

\subsection{Methane $\left(\mathrm{CH}_{4}\right)$}

Estimation of $\mathrm{CH}_{4}$ emission is obtained from rice cultivation practiced in Sarawak for wet paddy. Wet paddy needs sufficient amount of water and requires stagnant water conditions. In Sarawak, the cultivation period for rice conditions is 240 days for wet paddy. Based on calculations conducted in this study, it is estimated that the production from wet paddy in urban area for 2012 at Kuching, Miri and Sibu respectively is $0.60 \mathrm{Gg} \mathrm{CH}_{4} \mathrm{yr}^{-1}, 1.59 \mathrm{Gg}$ $\mathrm{CH}_{4} \mathrm{yr}^{-1}$ and $1.77 \mathrm{Gg} \mathrm{CH}_{4} \mathrm{yr}^{-1}$. While, for non-urban area for 2012 at Limbang, Sri Aman and Betong respectively is $0.53 \mathrm{Gg} \mathrm{CH}_{4} \mathrm{yr}^{-1}, 1.91 \mathrm{Gg} \mathrm{CH}_{4} \mathrm{yr}^{-1}$ and $1.25 \mathrm{Gg} \mathrm{CH}_{4} \mathrm{yr}^{-1}$.

Based on the results obtained in this study, it can be concluded the emission from 2008 to 2012 in urban areas has shown increasing trend but in non-urban areas has shown decreasing trend. Fig. 4 illustrates the $\mathrm{CH}_{4}$ emission from wet paddy for both urban and non-urban areas in Sarawak for year 2008-2012. 
In this study, the total uncertainties trend on $\mathrm{CH}_{4}$ emission from rice is approximately $10.41 \%$ for Kuching, $2.28 \%$ for Miri, $7.77 \%$ for Sibu, $2.94 \%$ for Limbang, 3.22\% for Sri Aman and $2.24 \%$ for Betong. It is found that the total uncertainties trend in GHG emissions from cropland for both urban and non-urban areas in Sarawak are less than 50\%.

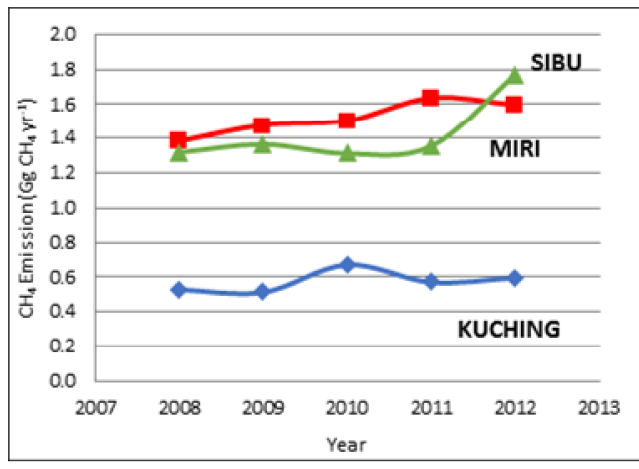

(a)

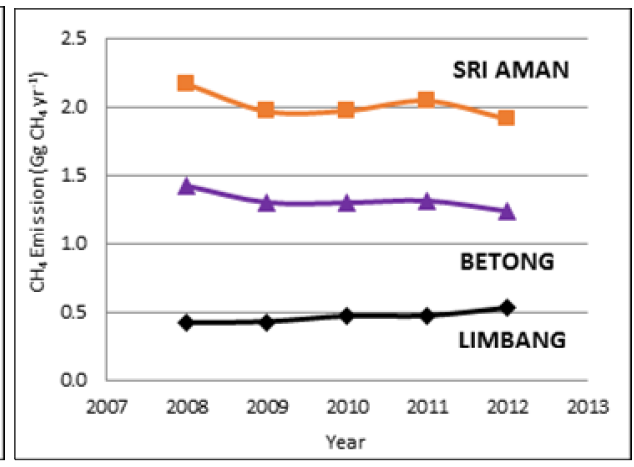

(b)

Fig. 4. Total annual $\mathrm{CH}_{4}$ emission from rice cultivation $\left(\mathrm{Gg} \mathrm{CH}_{4} \mathrm{yr}^{-1}\right)$ for wet paddy in (a) urban and (b) non-urban areas at Sarawak for year 2008-2012.

\section{Conclusions and Discussions}

The study determines GHG emission from cropland at both urban and non-urban areas in Sarawak. The total carbon released from cropland heavily depended on the crop types. In order to determine the amount of emission from perennial crops, estimation on changes of carbon stock in biomass cropland is conducted. As illustrated in Fig. 1, the trend of changes in biomass carbon stock from year 2008 till 2012 for perennial crops for urban area (Miri) in Sarawak, shows total oil palm are the highest emission of $\mathrm{CO}_{2}$ at $682.644 \times 10^{3}$ tons $\mathrm{C} \mathrm{yr}^{-}$ ${ }^{1}$. It is reported that oil palm plantations are being greatly expanded, largely in Sarawak and Borneo Island [6].

The annual amount of $\mathrm{CH}_{4}$ emitted from rice cultivation depends on the actual area of paddy being cultivated, number and duration of paddy grown, water regimes before and during cultivation period, as well as organic and inorganic soil amendments practiced [7]. For Sarawak, in the period of 2008 till 2012, it is found that total wet paddy contributed to the highest emission of $\mathrm{CH}_{4}$ is $1.91 \mathrm{Gg} \mathrm{CH}_{4} \mathrm{yr}^{-1}$ at Sri Aman. While, hill paddy produces almost negligible amount of $\mathrm{CH}_{4}$ emission. Hill paddy or upland rice fields, are not flooded, therefore this type of paddy do not produce significant quantities of $\mathrm{CH}_{4}$.

Finally, the results presented in this study showed the emissions from $\mathrm{CO}_{2}$ and $\mathrm{CH}_{4}$. These gases trap heat energy from the sun. GHG that exist in the atmospheric help maintain and stabilize the earth temperature. However, if the temperature of these gases increases excessively, it will cause global warming. Reduction of emissions from these gases cannot be done dramatically. Methods in managing land and growing crops need to be harmonized, for example by reducing the amount of nitrogen in fertilizing crop. Increase usage of nitrogen can lead to higher $\mathrm{N}_{2} \mathrm{O}$ emission. The increase of pasture quality to enhance animal productivity can reduce the amount of $\mathrm{CH}_{4}$ emitted per unit of animal product. Practicing organic farming technique could result in less $\mathrm{CH}_{4}$ being emitted to the atmosphere. In order to observe this situation, the GHG estimation established in this study can therefore be used for monitoring purposes.

The authors would like to thank UNITEN R\&D Sdn. Bhd for Grant U-EN-CR-14-12 that enabled collaboration which leads to the development of this paper. Any of the opinions, findings and 
conclusions expressed in this paper are those of the authors and do not reflect the views of UNITEN R\&D Sdn. Bhd.

\section{References}

[1] NC2, Malaysia's Second National Communication (NC2) to the UNFCCC, Ministry of Natural Resources and Environment, Malaysia, (2011)

[2] Sarawak Fact and Figures, State Planning Unit, Chief Minister's Department, Sarawak Agriculture Statistics (2008 - 2012), from http://www.spu.sarawak.gov.my

[3] Department of Agriculture, Sarawak, Sarawak Agriculture Statistics (2008-2012), Retrieved on June 25, 2016, from http://www.doa.sarawak.gov.my/modules/web/index.php

[4] IPCC, 2006 IPCC Guidelines for National Greenhouse Gas Inventories, Prepared by the National Greenhouse Gas Inventories Programme, Eggleston H.S., Buendia L., Miwa K., Ngara T. and Tanabe K. (eds).Published: IGES, Japan, (2006)

[5] BUR, Biennial Update Report to the UNFCCC, Ministry of Natural Resources and Environment, Malaysia, (2015)

[6] IPCC, Climate Change 2001: The Scientific Basis - Contribution of Working Group I to the Third Assessment Report of the Intergovernmental Panel on Climate Change (IPCC). Cambridge, UK, Cambridge University Press, (2001)

[7] H. Neue, R. L. Sass, Trace Gas Emissions from Rice Fields, Int. J. of Environmental Science Research, 48, 119-147, (1994)

[8] IPCC, Revised 1996 IPCC Guidelines for National Greenhouse Gas Inventories: 1-3. Houghton, J.T., Meira Filho, L.G., Lim, B., Tréanton, K., Mamaty, I., Bonduki, Y., Griggs, D.J. and Callander, B.A. (Eds). Intergovernmental Panel on Climate Change (IPCC), IPCC/OECD/IEA, Paris, France, (1996) 